Канд. техн. наук Т.В. Шелейко (ДП «УкрНДІВ»)

\title{
ДОСЛІДЖЕННЯ ХАРАКТЕРИСТИК ГАЛЬМІВНИХ СИСТЕМ З ВИКОРИСТАННЯМ МЕТОДІВ МАТЕМАТИЧНОЇ СТАТИСТИКИ
}

\section{Представив д-р техн. наук, професор І.Е. Мартинов}

Постановка проблеми. Поява нових більш потужних засобів гальмування зумовлює необхідність проведення більш ретельних досліджень функціонування як самої гальмівної системи в цілому, так і окремих іiі елементів для більш повного використання можливої у кожному конкретному випадку сили зчеплення коліс 3 рейками $з$ урахуванням деякої імовірності проковзування колеса відносно рейки, що завжди має місце в експлуатації. 3 огляду на те, що перспективними напрямами вантажного вагонобудування $\epsilon$ збільшення осьового навантаження і швидкостей руху (основних факторів, від яких залежить адекватна (оптимальна) робота гальмівної системи), такі дослідження набувають додаткового значення. 
Оскільки на процес взаємодії колеса i гальмівної колодки незалежно один від одного впливають численні фактори, то змінювані величини процесу реалізації гальмівної сили $є$ також випадковими і для ïx дослідження слід використовувати методи теорії імовірності, які дозволяють компенсувати недостатність знань характеру процесів і неможливість повного врахування конкретних законів змінювання кожного фактора закономірностями їх масового прояву. Підставою для застосування цих методів має бути достатньо великий обсяг експериментальних даних (у тому числі даних 3 експлуатаціі), що дозволив би оцінити стан питання, виявити закономірності виникнення i розподілу досліджуваної випадкової величини для прийняття відповідних заходів чи надання рекомендацій 3 його усунення або стабілізації [1].

Аналіз останніх досліджень і публікацій. Методи математичного аналізу до процесів гальмування застосовуються не вперше [2, 3]. Так, для екіпажів без протиюзних пристроїв рівень гальмівних сил за повного службового гальмування обирають, виходячи 3 імовірності їх без'юзового гальмування (за екстреного або повного службового гальмування), що має бути не менше ніж 0,9. Окрім середніх рівнів гальмівних сил і сил зчеплення, на залізниці ця імовірність характеризується величинами природних розкидів як сил зчеплення вагонних коліс 3 рейками під час гальмування, так i гальмівних сил. Зменшення ж амплітуд цих розкидів дозволить зменшити імовірність пошкодження коліс завдяки зменшенню імовірності виникнення юзової ситуації та (або) підвищити середній рівень гальмівних сил за повного службового та екстреного гальмувань рухомого складу.

\section{Мета статті. Дослідити} характеристики колодкової гальмівної системи за результатами стаціонарних, поїзних i стендових випробувань як випадкові величини, застосовуючи теорію випадкових процесів, методи теорії імовірності і математичної статистики.

Дослідження сили натиснення гальмівних колодок за результатами стаціонарних випробувань гальмівної системи. Під час проведення розрахункових досліджень гальмівних характеристик чи гальмівної ефективності вантажного вагона припускається, що сила натиснення колодок на колеса розподіляється рівномірно. Однак численні експериментальні дослідження свідчать, що сили натиснення гальмівних колодок розподіляються нерівномірно не тільки по осях вагона, але й у межах однієї колісної пари (рис. 1).

Як альтернатива типовій, останнім часом усе більшого застосування на вантажних вагонах набувають роздільні гальмівні системи (рис. 2). Дослідження гальмівних характеристик гальмування обох систем [4] як випадкових величин (рис. 1-4) дали підстави стверджувати, що:

$\checkmark$ нерівномірний розподіл сил натиснення гальмівних колодок на колісні пари зумовлений недосконалістю конструкції важільної передачі;

$\checkmark$ найбільш навантаженими під час гальмування є зовнішні колісні пари;

$\checkmark$ роздільна гальмівна система забезпечує більшу гальмівну ефективність, менші відхилення значень сили натиснення, тому її застосування дозволить підвищити стабільність гальмівних характеристик, а правильний підбір передаточного числа важільної передачі роздільної гальмівної системи дозволить не тільки забезпечити максимальну гальмівну ефективність вантажного вагона, але й знизити імовірність виникнення юзових ситуацій в експлуатації.

Таким чином, оцінювання розкиду значень характеристик гальмівної системи на іiі відповідність нормативним вимогам дозволяє підвищити достовірність результатів стаціонарних гальмівних випробувань для прийняття, у разі необхідності, додаткових заходів або зі зниження імовірності виникнення юзу колісних пар вантажного вагона в експлуатації, або 3 підвищення його гальмівної ефективності. 
a)

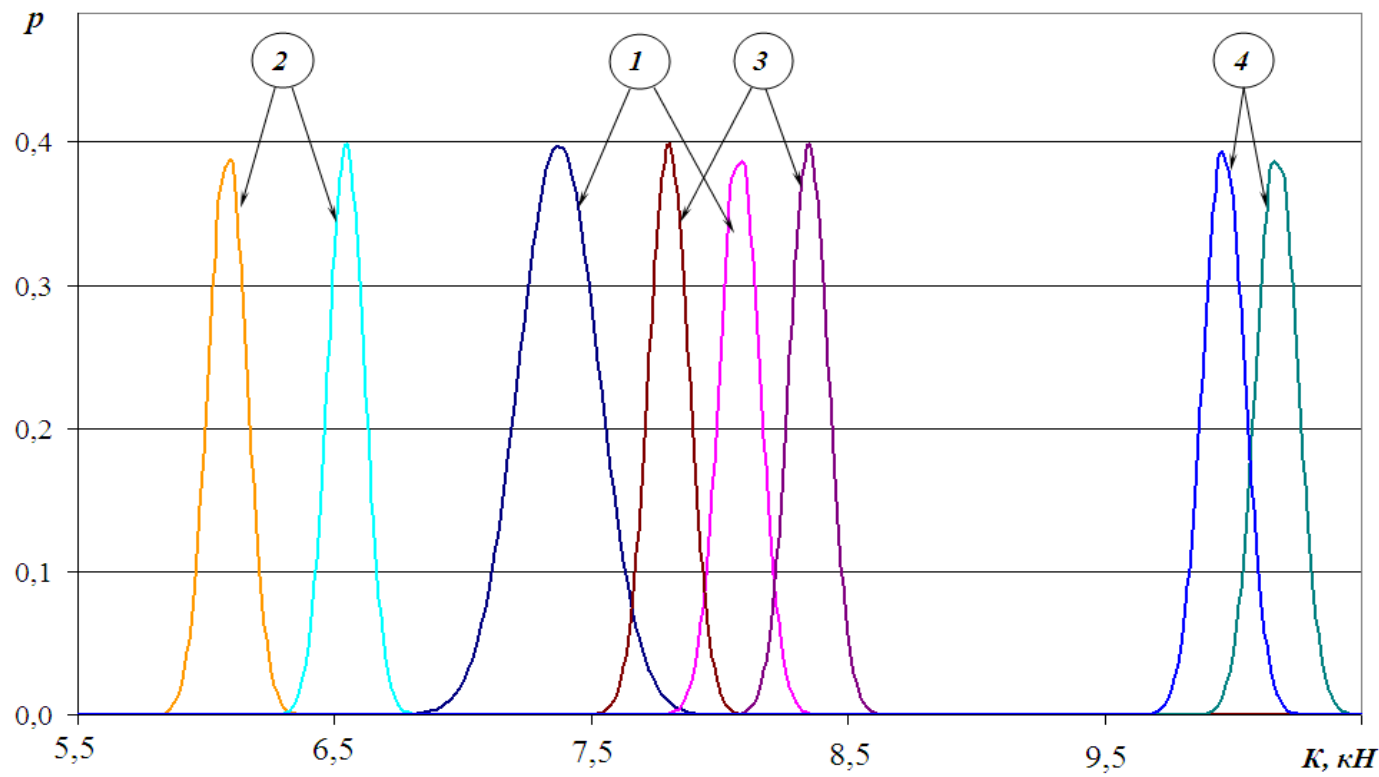

б)

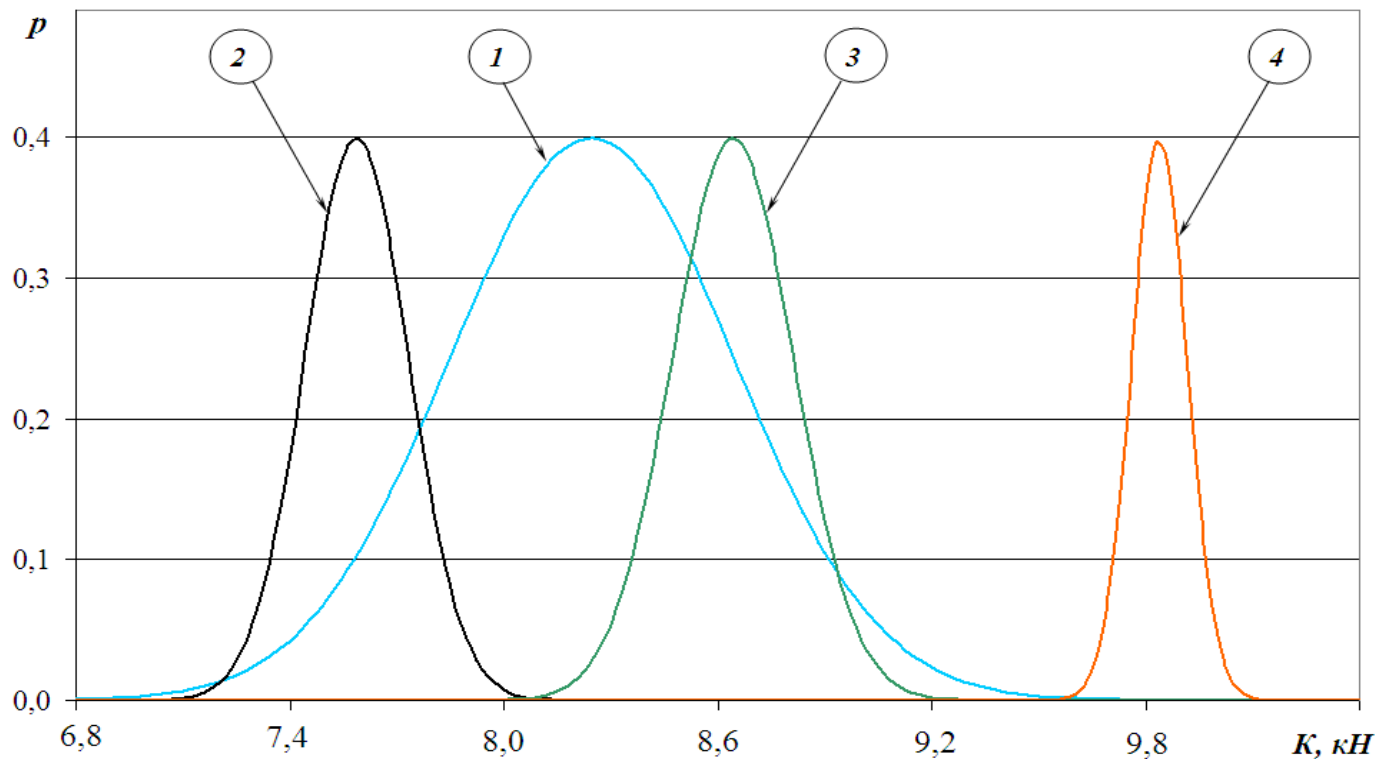

B)

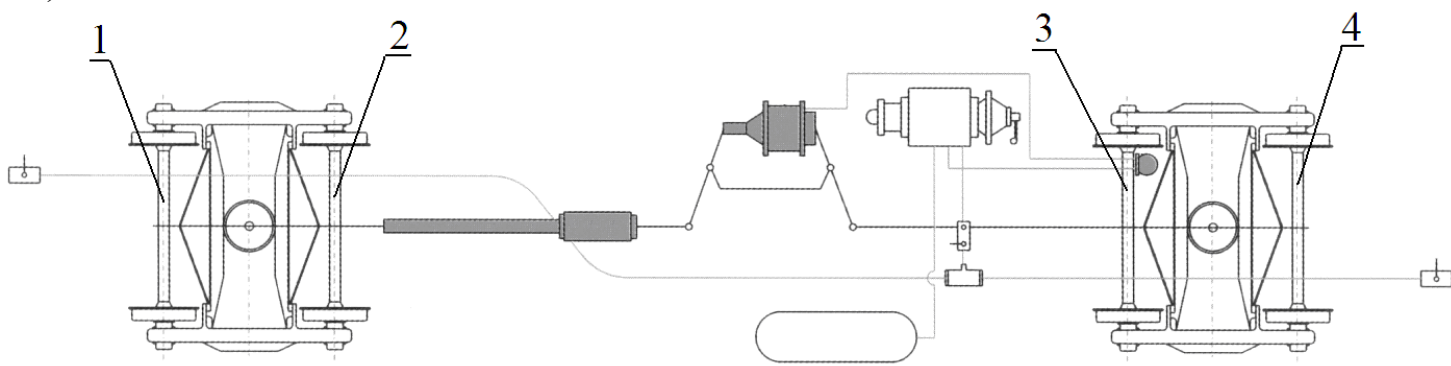

Рис. 1. Густина розподілів дійсних сил натиснення гальмівних колодок на колеса (а) та по осях (б) вантажного вагона 3 типовою гальмівною системою (в) $(1-4$ - осі колісних пар) 
a)

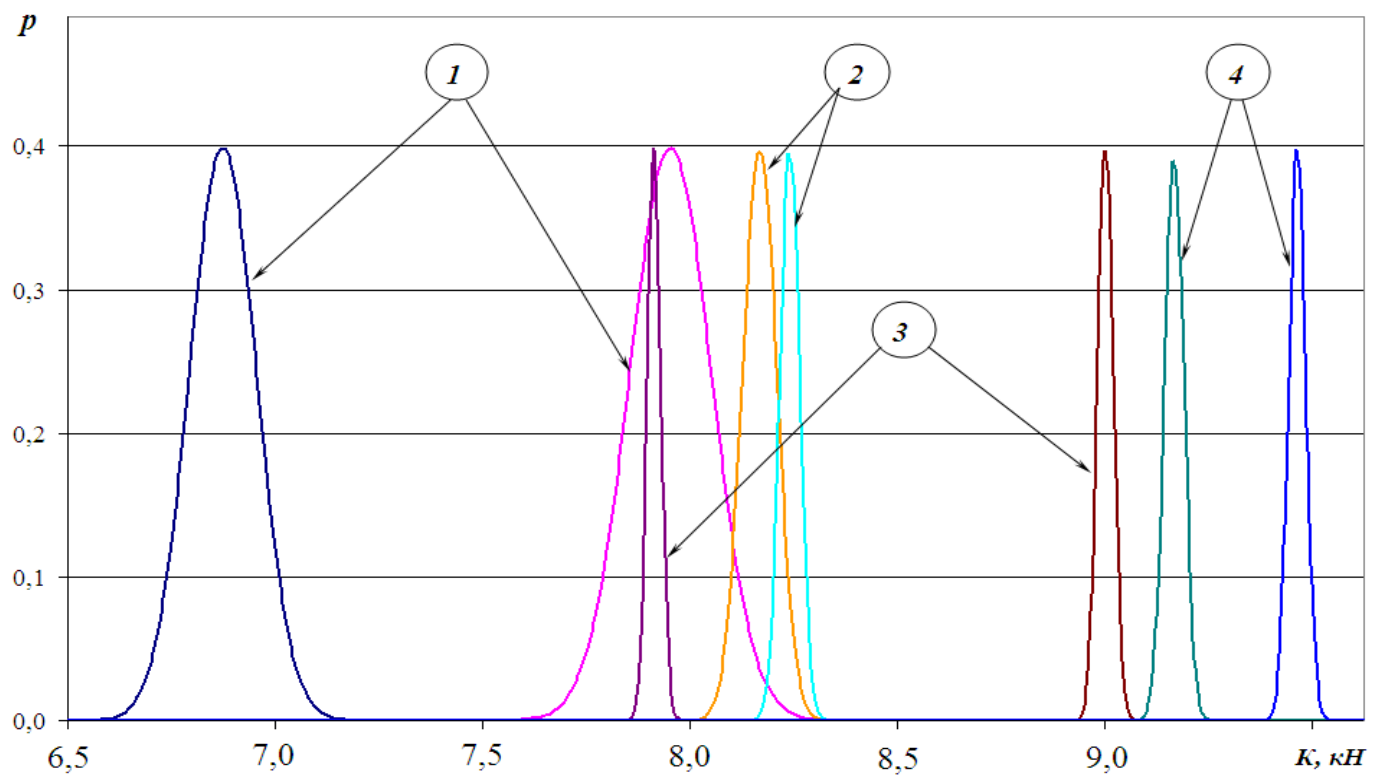

б)

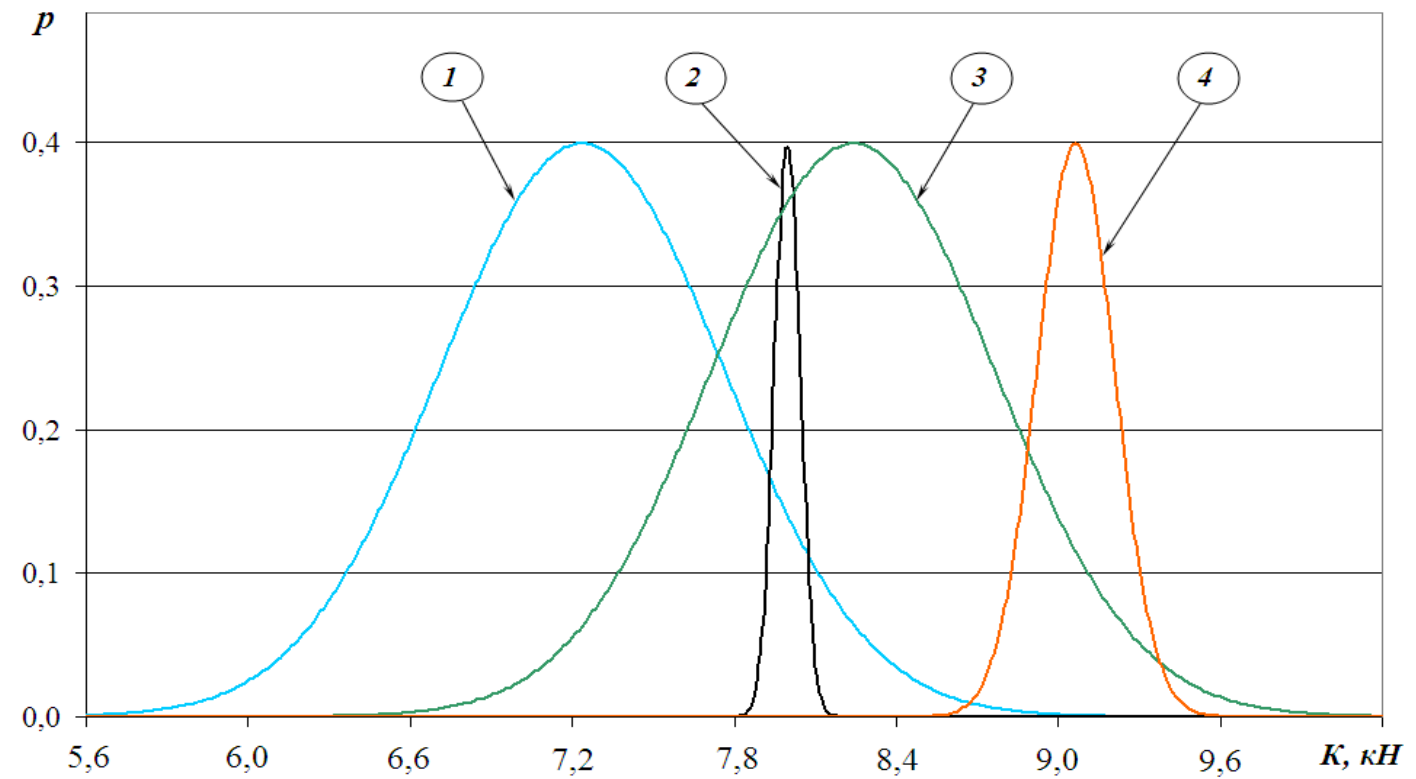

в)

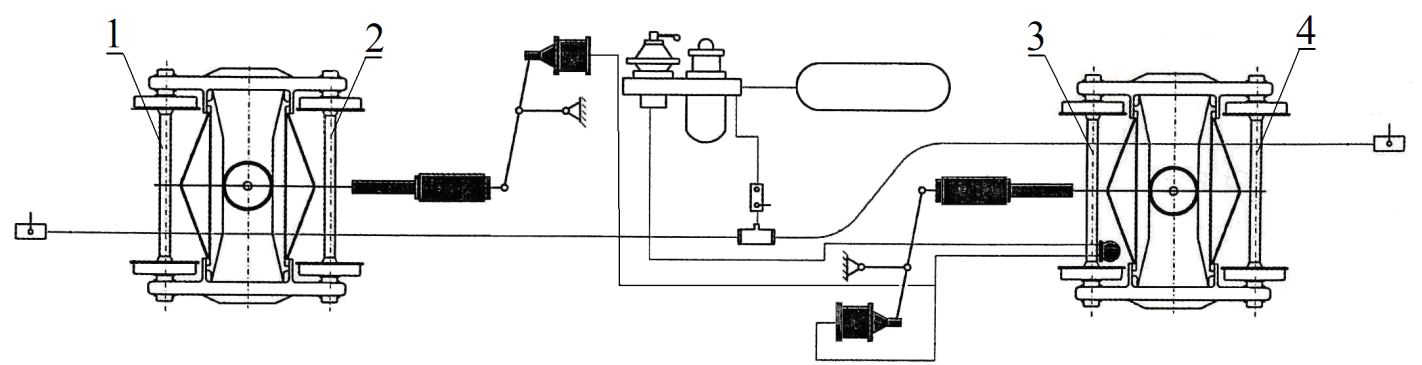

Рис. 2. Густина розподілів дійсних сил натиснення гальмівних колодок на колеса (а) та по осях (б) вантажного вагона з роздільною гальмівною системою (в) (1 - 4 - осі колісних пар) 


\section{Рухомий склад залізниць}

a)

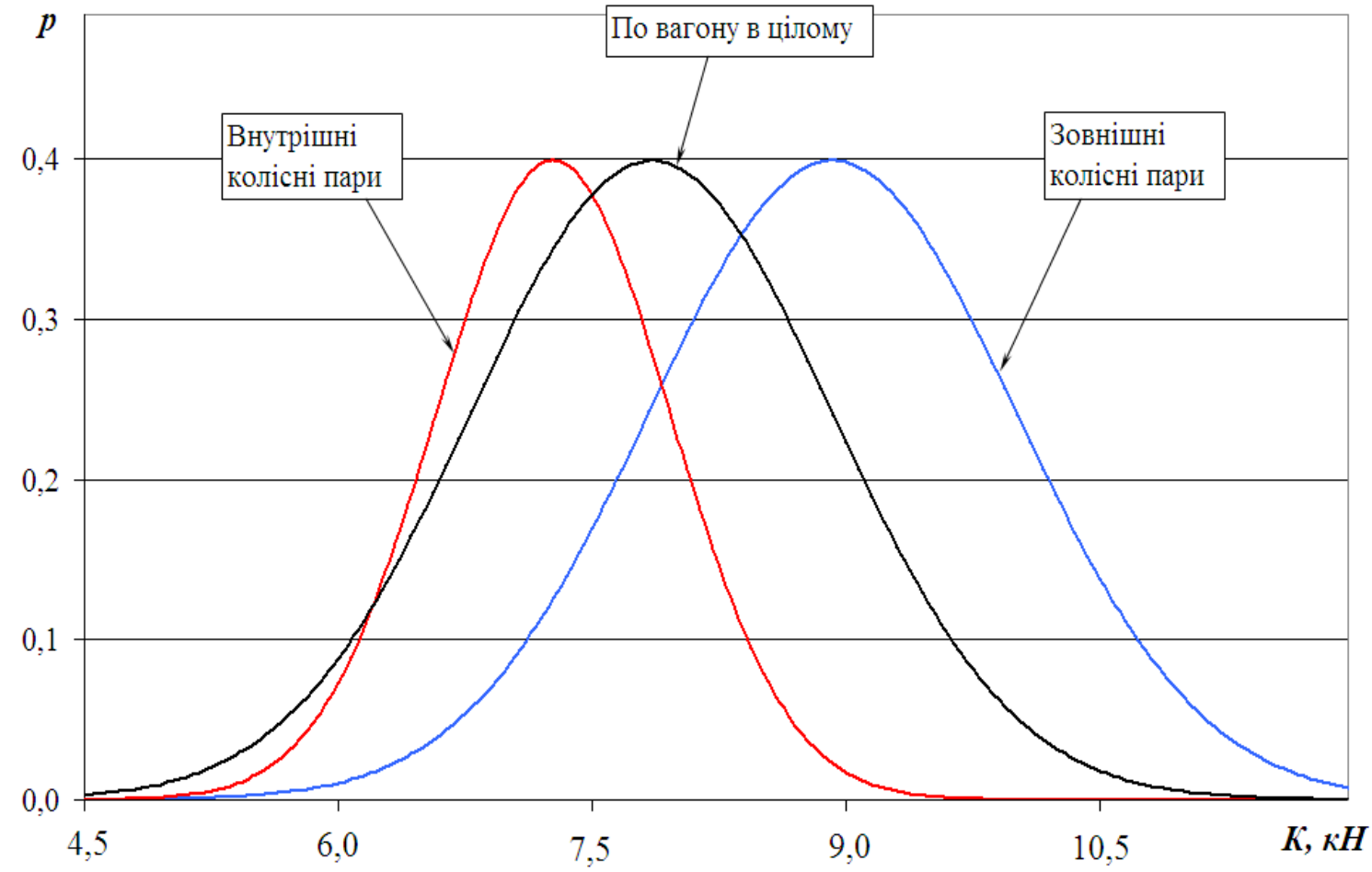

б)

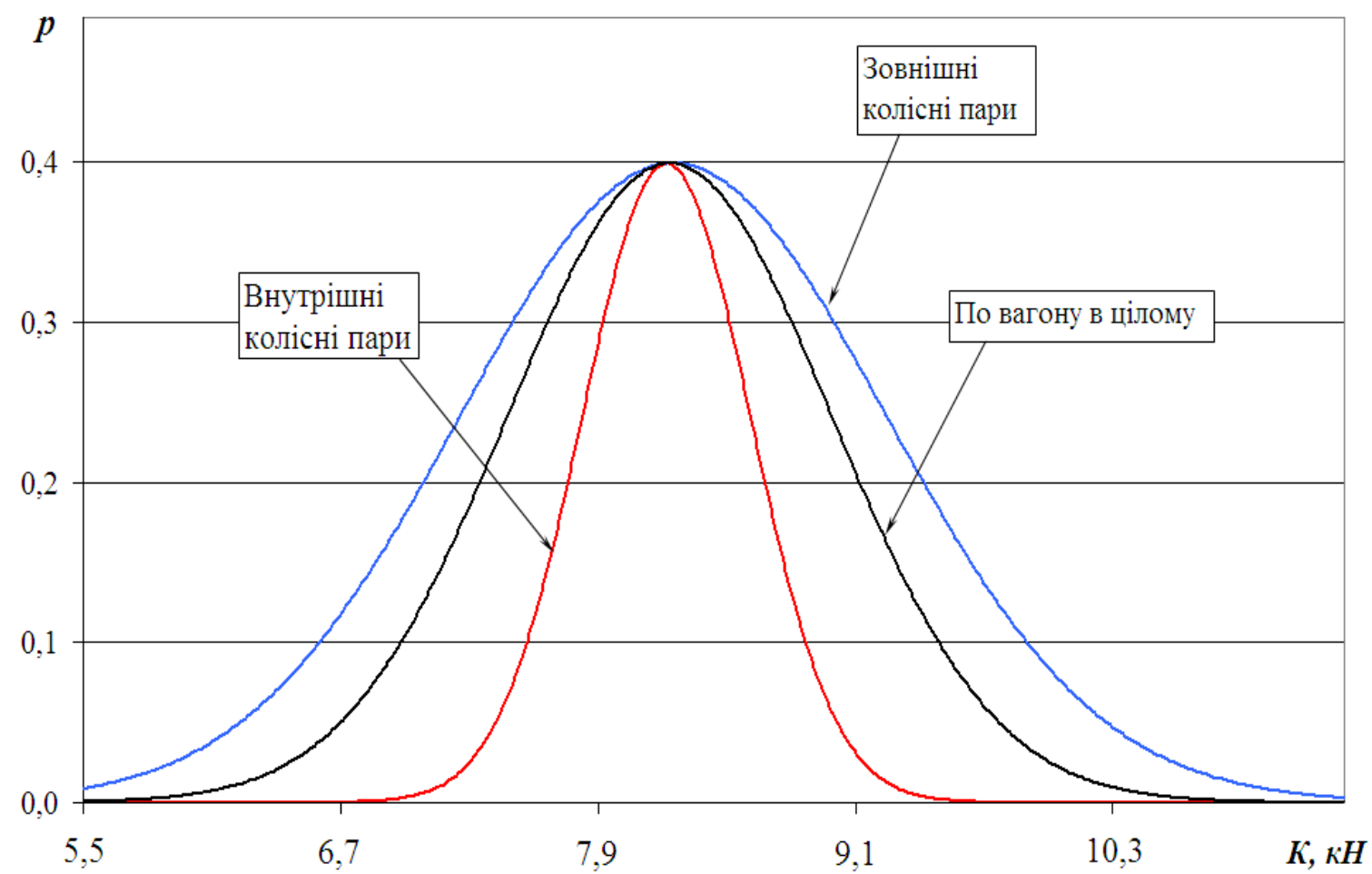

Рис. 3. Густина розподілів сумарних дійсних сил натиснення гальмівних колодок на колеса вантажного вагона 3 типовою (а) і роздільною гальмівною системою (б) 
a)

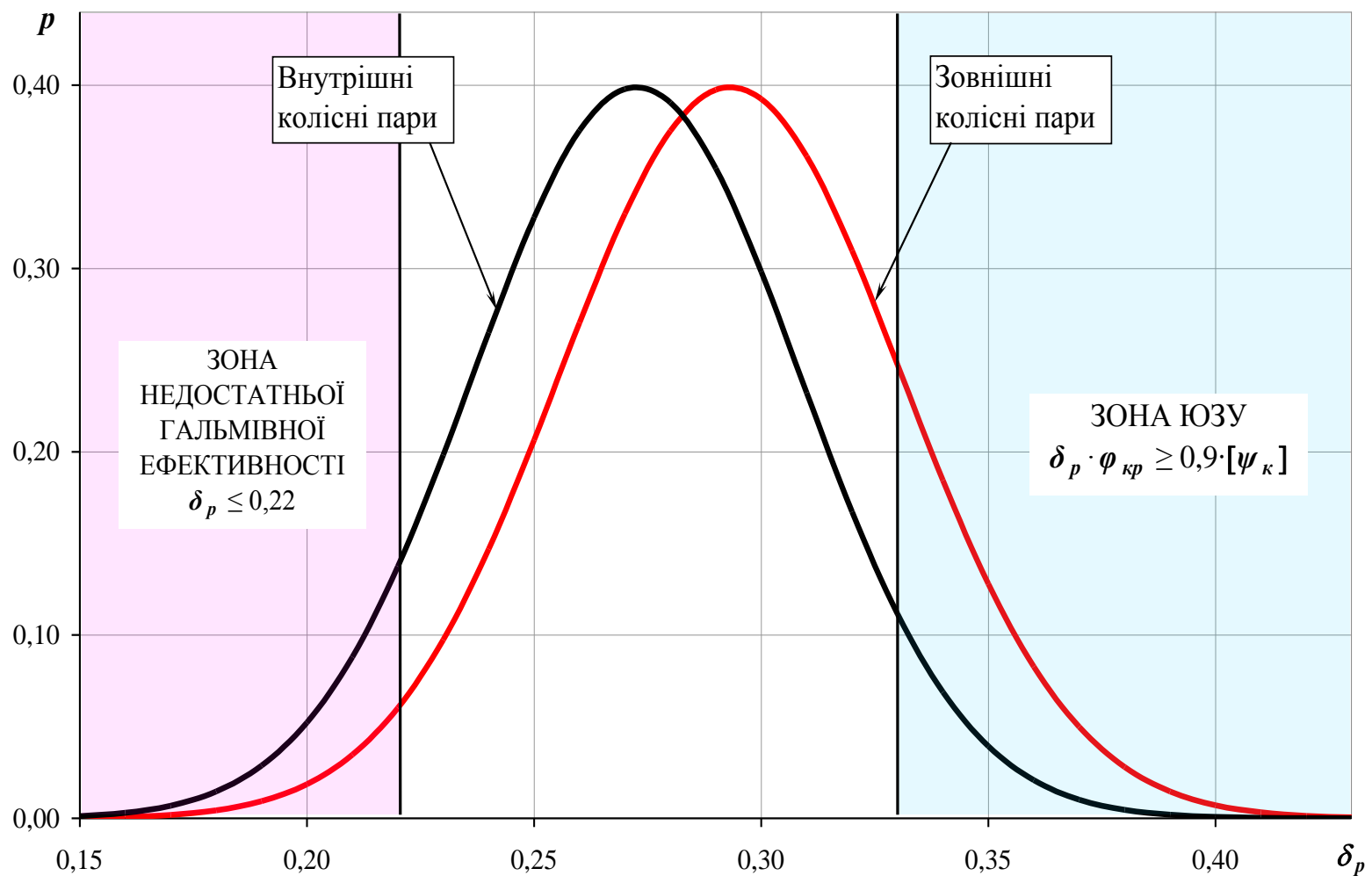

б)

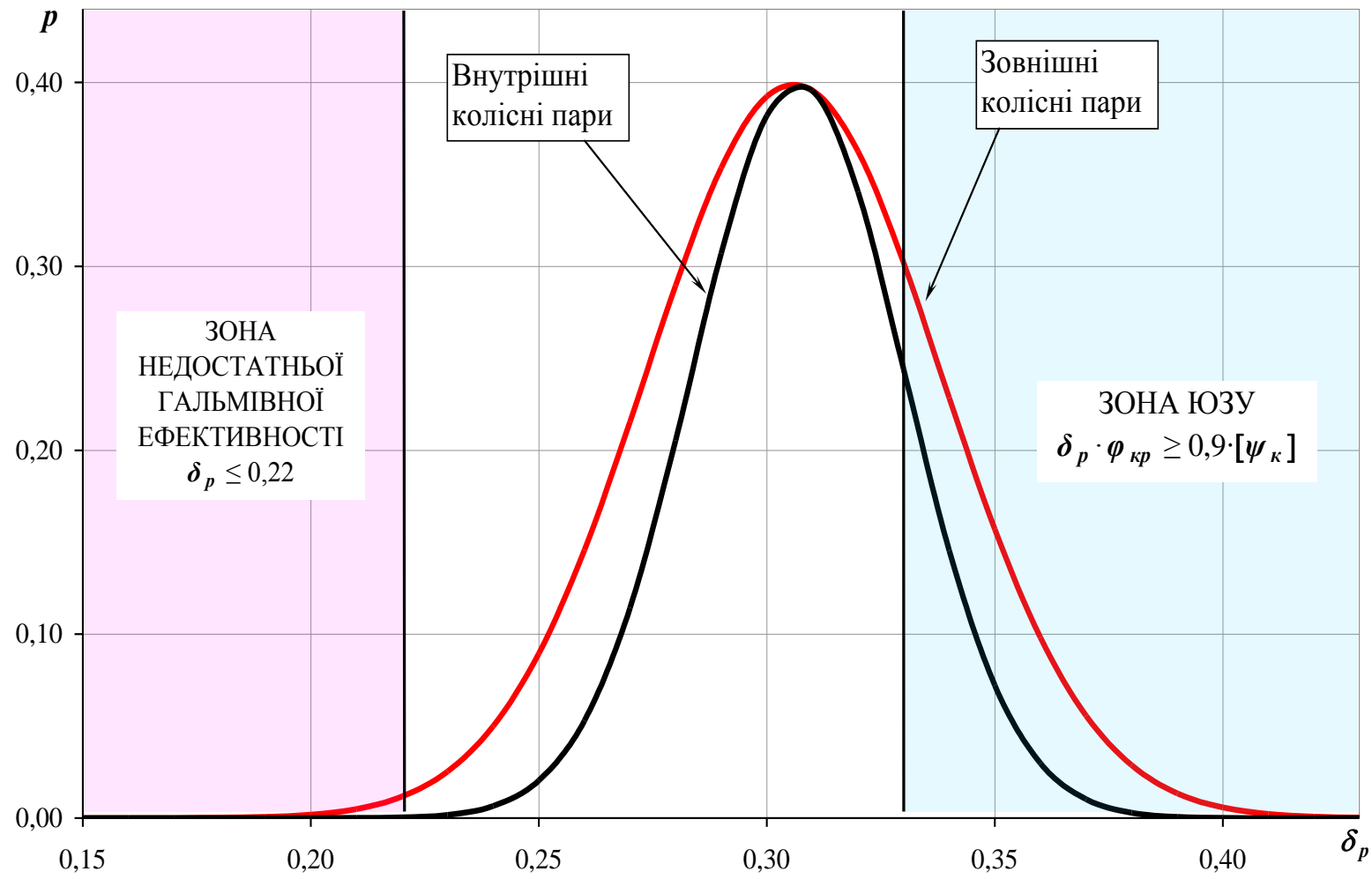

Рис. 4. Густина розподілів величини розрахункового коефіцієнта сумарних сил натиснення гальмівних колодок на колеса вантажного вагона з типовою (а) і роздільною гальмівною системою (б) 


Дослідження фрикційних власти-
возькі - до недостатньої гальмівної
востей гальмівних колодок за
результатами стендових випробувань.

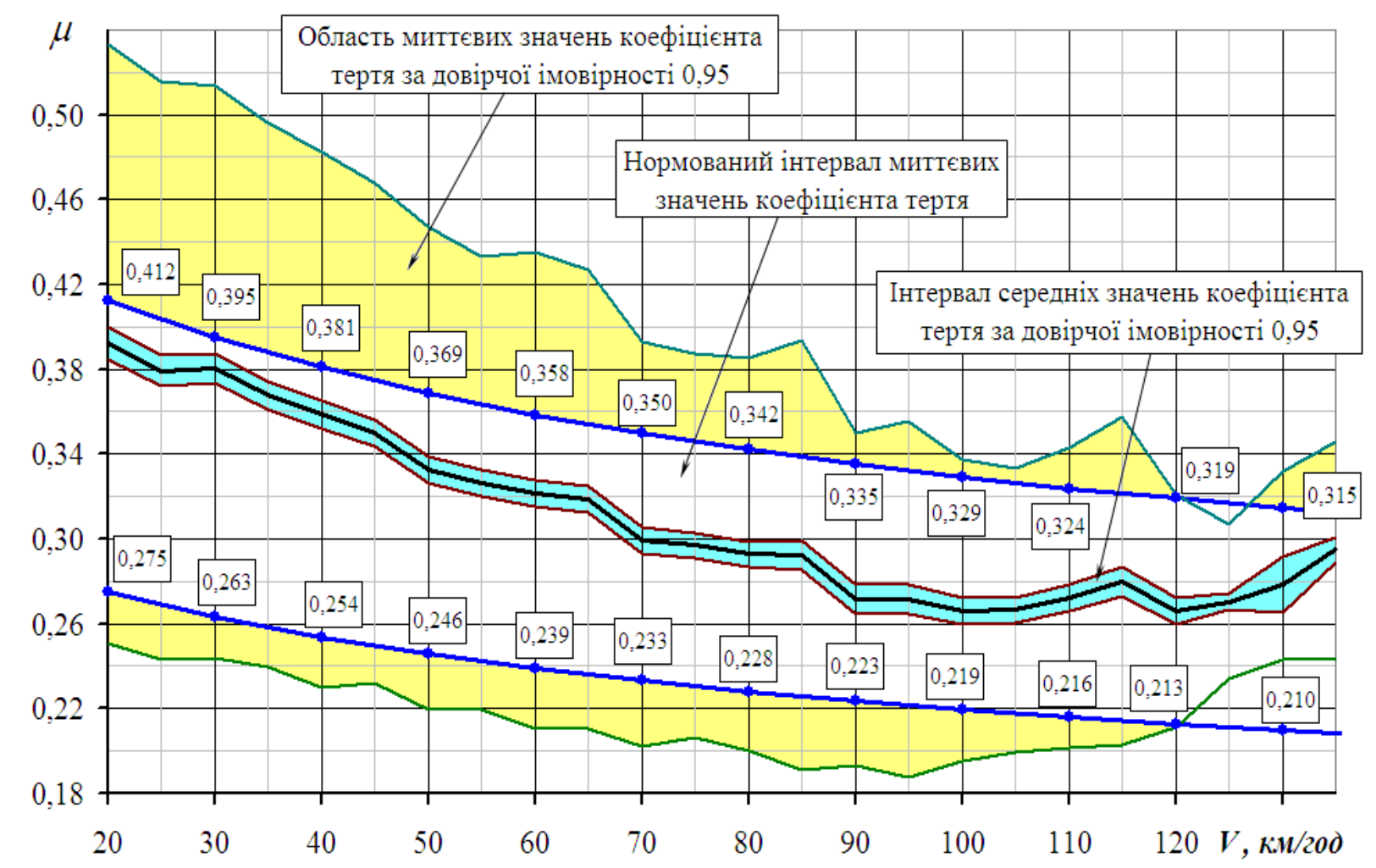

Рис. 5. Відхилення миттєвих значень коефіцієнта тертя

Подальший аналіз показав високу імовірність перевищення коефіцієнтом тертя максимальних нормованих значень (рис. 6), імовірність виникнення юзової ситуації при цьому склала до 5 \% (рис. 7). 
Рухомий склад залізниць

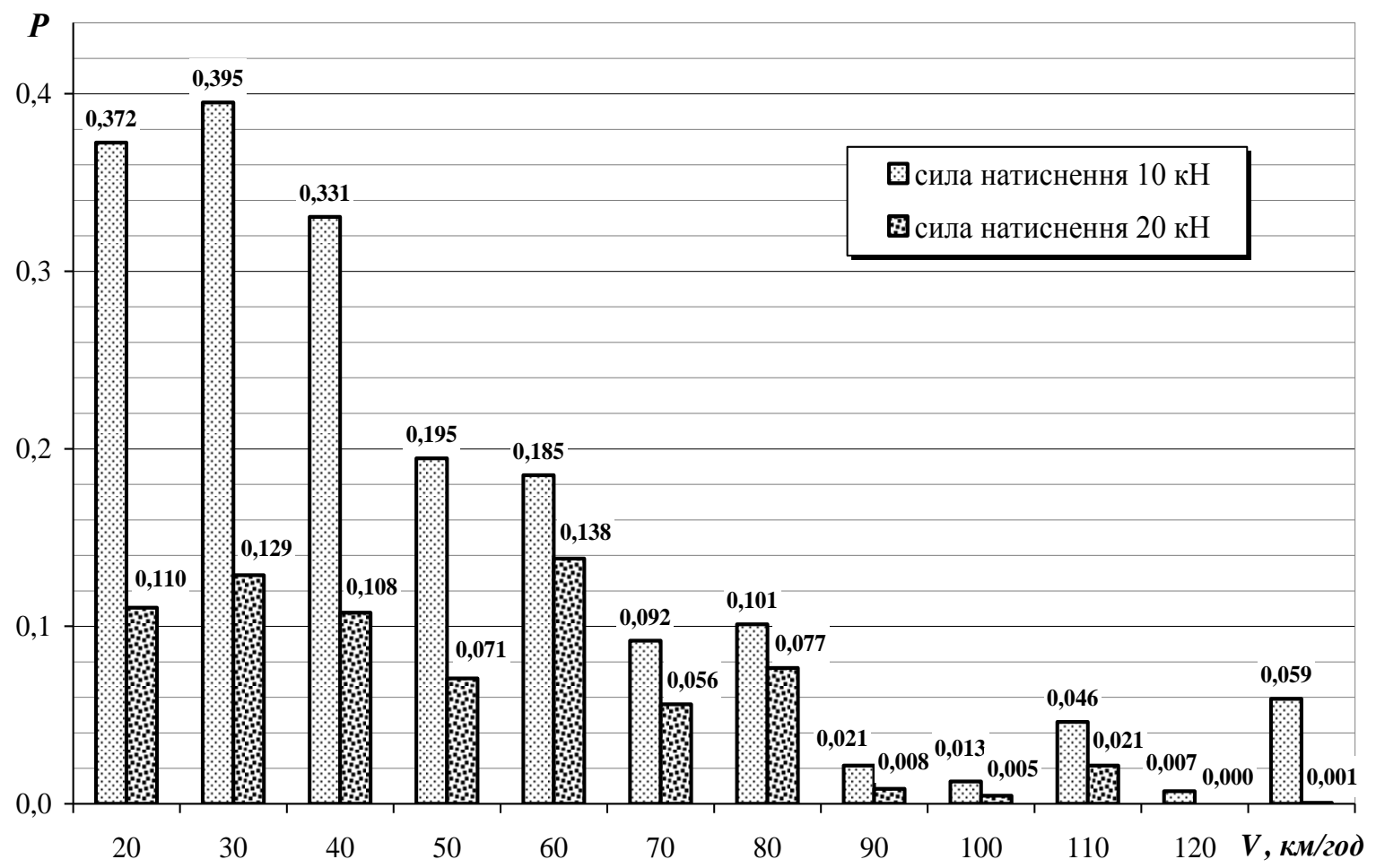

Рис. 6. Імовірність перевищення миттєвими значеннями коефіцієнта тертя нормованих максимальних значень

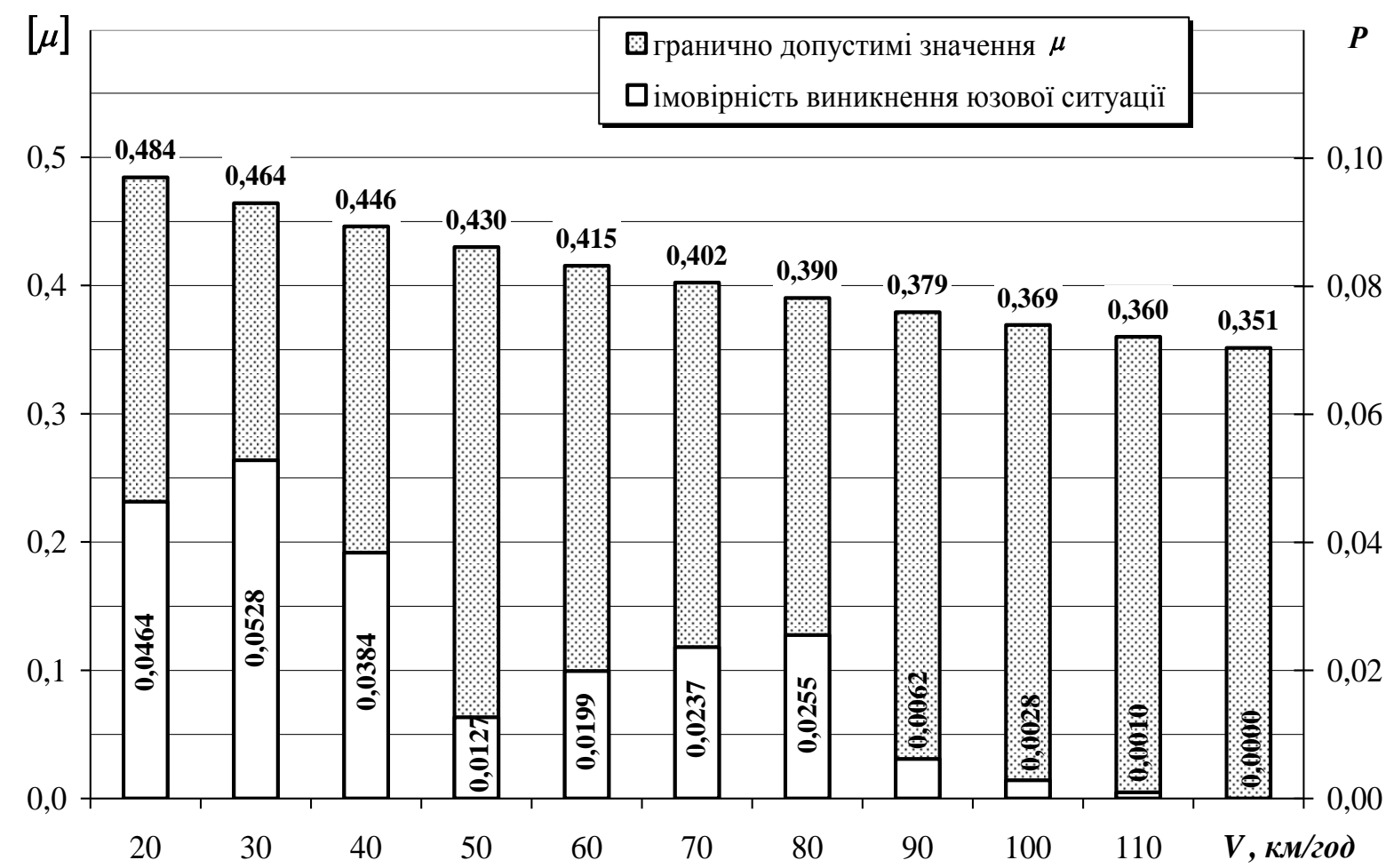

Рис. 7. Імовірність виникнення юзової ситуації та гранично допустимі значення коефіцієнта тертя 
Таким чином, оцінювання коефіцієнта тертя гальмівних колодок за результатами випробувань на інерційному стенді як випадкової величини 3 використанням методів математичної статистики та теорії імовірності дозволяе проводити більш глибокий аналіз фрикційних властивостей гальмівних колодок і оцінювати імовірність виникнення юзової ситуації ще на етапі проектування вагонів та створення нових композиційних гальмівних колодок.

\section{Дослідження}

розрахункового коефіціснта сили натиснення гальмівних колодок за результатами поїзних випробувань гальмівної системи. Подальше удосконалення гальмівних систем, 3 урахуванням прийнятого напрямку на створення високошвидкісного транспорту, потребує для їх ефективного та якісного дослідження застосування більш точних методів визначення гальмівного шляху, таких як метод «кидання», та досконалішого

випробувального обладнання для підвищення точності визначення гальмівних характеристик досліджуваного вагона. При цьому важливого значення набувають питання аналізу i оцінки результатів гальмівних випробувань та ухвалення рішення про відповідність або невідповідність їх нормативним вимогам.

3 метою визначення ступеня впливу різних чинників на достовірність і точність гальмівних випробувань були проведені розрахункові дослідження 3 оцінювання невизначеності вимірювань розрахункового коефіцієнта сили натиснення гальмівних колодок за різних швидкостей руху на початку гальмування під час проведення поїзних гальмівних випробувань за методом кидання [6]. Підсумкові значення визначалися за довірчої імовірності 0,95 (рис. 8).

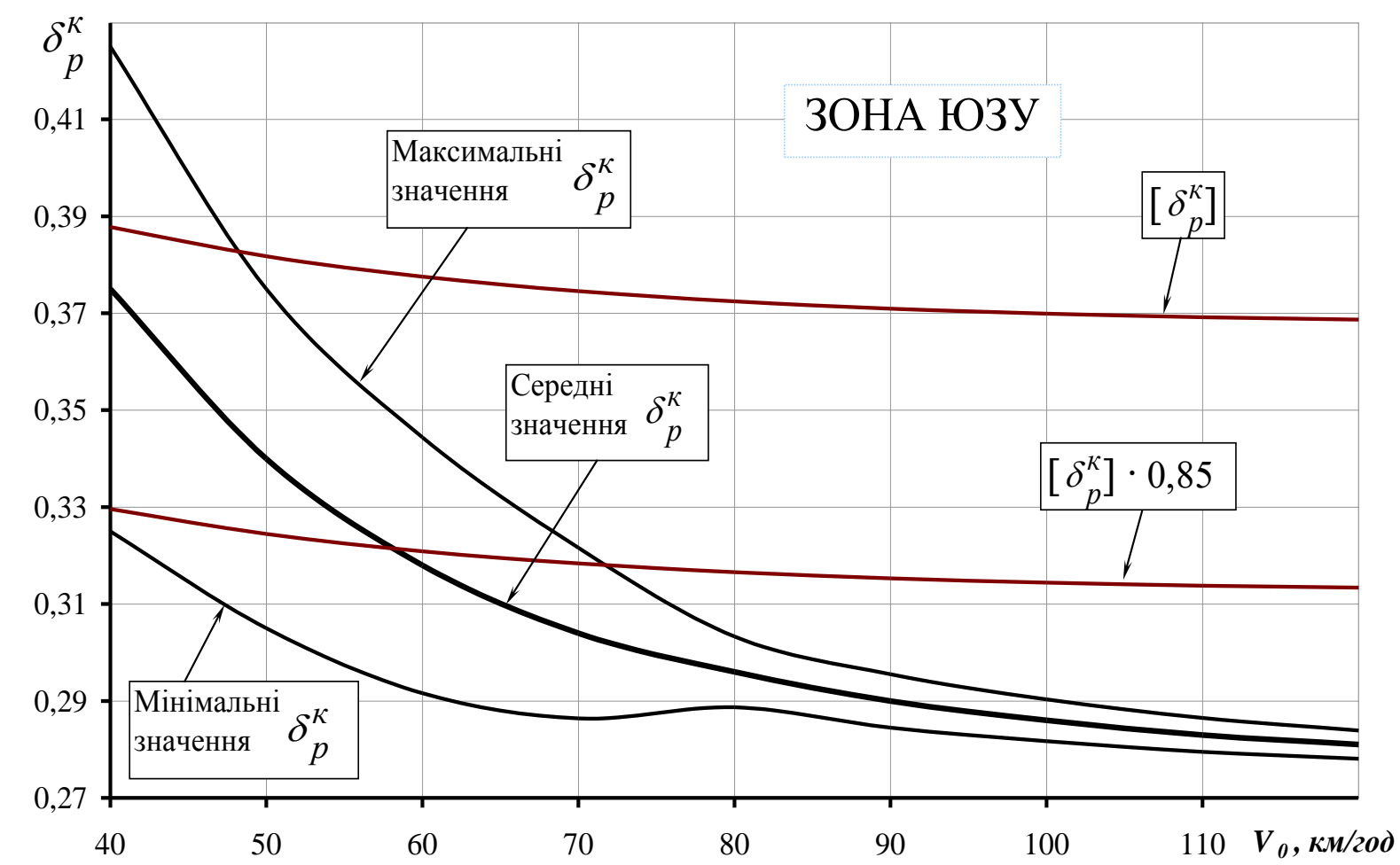

Рис. 8. Розкид значень, що з імовірністю 0,95 можуть бути приписані розрахунковому коефіцієнту сили натиснення композиційних гальмівних колодок 
Виконані розрахунки показали, що для швидкості 40 км/год і максимального значення розрахункового коефіцієнта можлива юзова ситуація, імовірність перевищення допустимого коефіцієнта зчеплення колеса 3 рейкою складає 0,22 (рис. 9).

3 аналізу $є$ очевидним, що у досліджуваного вагона відсутній запас по юзу на малих (до 50 км/год) швидкостях руху під час гальмування і малий у разі швидкостей руху до 70 км/год. Тому, 3 метою зниження імовірності виникнення юзової ситуації в експлуатації, для досліджуваного вагона необхідно прийняти додаткові заходи, як, наприклад, зменшення передаточного числа важільної передачі або зниження тиску у гальмівному циліндрі.

Таким чином, оцінювання результатів гальмівних випробувань 3 урахуванням невизначеності вимірювань дозволяє отримувати уточнену оцінку характеристик гальмівної системи для заданої довірчої імовірності та отримувати більш повну i достовірну інформацію стосовно властивостей гальмівних систем рухомого складу та їх відповідності нормативним вимогам.

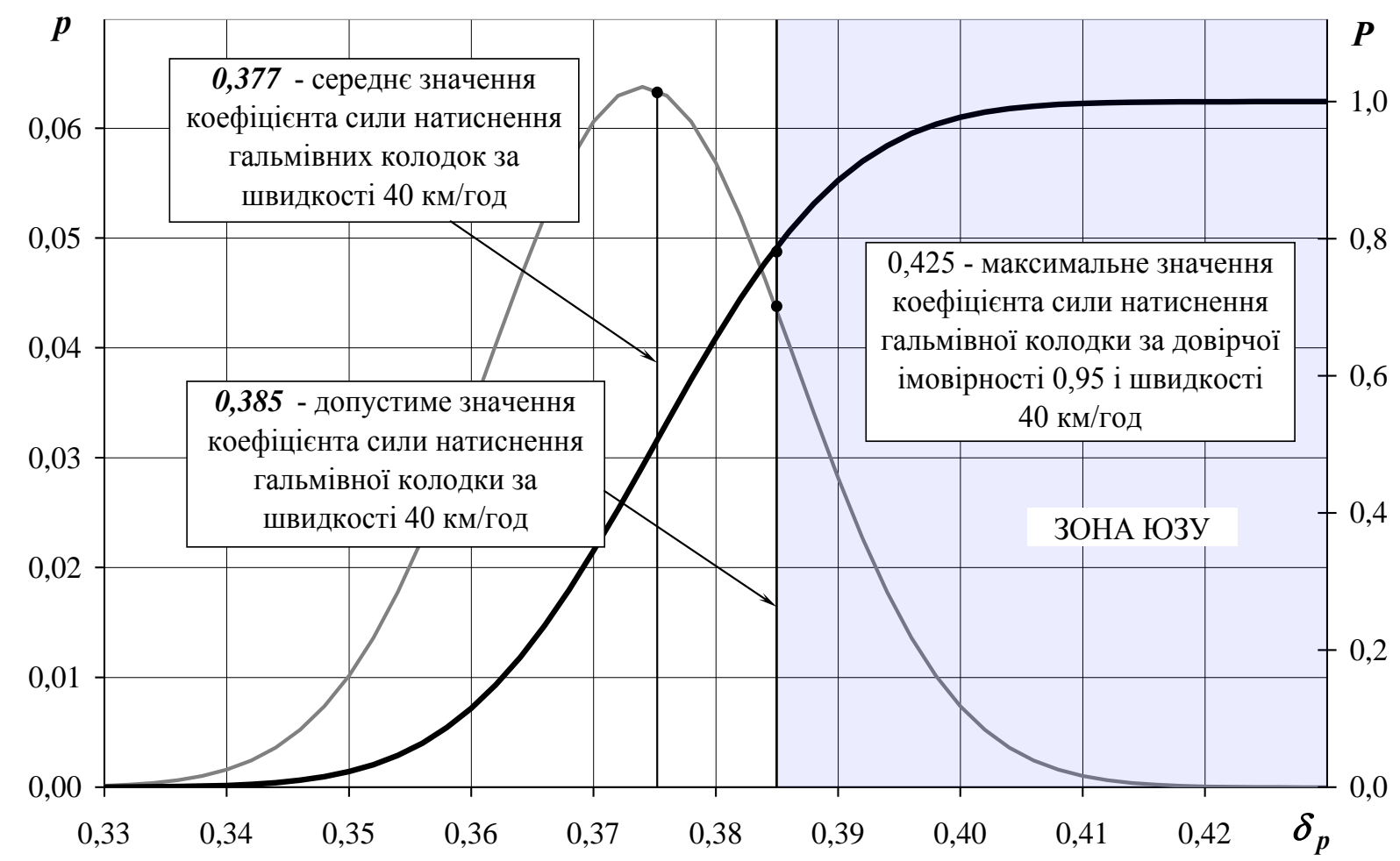

Рис. 9. Функція розподілу і щільність розрахункового коефіцієнта сили натиснення гальмівних колодок для швидкості руху на початку гальмування 40 км/год

Висновки. Виконані розрахункові дослідження доводять, що:

$\checkmark$ оцінювання розкиду значень характеристик гальмівної системи на відповідність нормативним вимогам дозволяе підвищити достовірність результатів гальмівних випробувань для прийняття, у разі необхідності, додаткових заходів або зі зниження імовірності виникнення проковзування коліс під час гальмування вантажного вагона, або 3 підвищення його гальмівної ефективності; $\checkmark$ оцінювання фрикційних властивостей гальмівних колодок 3 
урахуванням виходу миттєвих значень коефіцієнта тертя за межі нормованого інтервалу дозволяє проводити більш глибокий аналіз фрикційних властивостей гальмівних колодок і оцінювати імовірність виникнення юзової ситуації ще на етапі проектування вагонів;

$$
\checkmark \text { результати досліджень }
$$
характеристик гальмування як випадкових величин можуть бути використані для визначення напрямків та об'єктів подальших досліджень 3 оптимізації процесів функціонування елементів гальмівної системи вантажних вагонів нового покоління або підвищення гальмівної ефективності вантажних вагонів існуючого парку.

Таким чином, розгляд характеристик гальмування як випадкових величин i застосування для їх дослідження методів математичного аналізу дозволяє у сучасних ринкових умовах, які характеризуються насамперед обмеженістю фінансових ресурсів, здійснювати не тільки контроль використання наявного потенціалу будьякого процесу, а й створює умови для розроблення та подальшої реалізації успішної стратегії з його покращення.

\section{Сиисок літератури}

1. Шелейко, Т.В. Загальні методи досліджень процесів функціонування елементів колодкової гальмівної системи [Текст] / Т.В. Шелейко, Ю.Я. Водянніков, С.М. Свистун // Залізничний транспорт. - 2012. - № 1. - С. 13-15.

2. Старченко, В.М. Наукові основи підвищення ефективності гальмування поліпшенням умов взаємодії коліс 3 гальмівними колодками і рейками [Текст]: автореф. дис. ... д-ра техн. наук: 05.22.07 / В.М. Старченко. - Луганськ, 2008. - 25 с.

3. Жаров, И.А. Проблемы триботехнических инноваций на железнодорожном транспорте [Текст] / И.А. Жаров // Вестник ВНИИЖТ. - 2007. - № 5. - С. 8-11.

4. Донченко, А.В. Дослідження сил натиснень гальмівних колодок в процесі гальмування вантажного вагона [Текст] / А.В. Донченко, Ю.Я. Водянніков, Т.В. Шелейко // Зб. наук. праць ДП «УкрНДІВ». Рейковий рухомий склад. - Кременчук, 2012. - Вип. 6. C. $72-79$.

5. Водянников, Ю.Я. Анализ и оценка фрикционных свойств тормозной колодки при испытаниях на инерционном стенде [Текст] / Ю.Я. Водянников, Т.В. Шелейко, А.Е. Нищенко // Зб. наук. праць ДЕТУТ. Серія «Транспортні системи і технології». - К.: ДЕТУТ, 2010. - Вип. 17. - С. 29-40.

6. Донченко, А.В. Оцінка гальмівної ефективності вантажного вагона з урахуванням похибки вимірювань [Текст] / А.В. Донченко, Ю.Я. Водянніков, Т.В. Шелейко // Зб. наук. праць. - Харків: УкрДАЗТ, 2011. - Вип. 122. - С. 152-160.

Ключові слова: колодкова гальмівна система, характеристика гальмівної системи, густина розподілу.

\section{Анотаціï}

Обгрунтовано доцільність застосування методів математичної статистики під час аналізу гальмівних систем одиниць рухомого складу і дослідження їх характеристик як випадкових величин, що дозволяє здійснювати не тільки контроль використання наявного потенціалу будь-якого процесу, а й створює умови для розроблення та подальшої реалізації успішної стратегії з його покращення. 
Обоснована целесообразность применения методов математической статистики при анализе тормозных систем единиц подвижного состава и исследовании их характеристик как случайных величин, что позволяет осуществлять не только контроль использования имеющегося потенциала любого процесса, но и создает условия для разработки и последующей реализации успешной стратегии по его улучшению.

Suitability of application of mathematical statistics methods for analysis of brake systems of rolling stock and study of their characteristics as random values was proved. It allows not only to control the use of existing potential of any process, but also establishes conditions for development and further successful implementation of its improvement strategy. 